\title{
Commentary: The Barlow valve: Understanding disease and symmetry
}

\author{
Carlos A. Mestres, MD, PhD, FETCS, ${ }^{a, b}$ \\ Miguel A. Piñón, $\mathrm{MD}, \mathrm{PhD},{ }^{\mathrm{c}}$ and \\ Eduard Quintana, MD, PhD, FETCS ${ }^{\mathrm{d}}$
}

Mitral valve repair is the gold standard in the surgery of degenerative mitral valve disease, a solidly established option supported by practice guidelines ${ }^{1}$ despite discussion. ${ }^{2}$ The main goal of repair is achieving valve competence. ${ }^{3}$ Of special interest is the complex described by the late John Barlow in 1963, known as the Barlow valve or Barlow disease. His description of late systolic murmur and malignant cardiac arrhythmias triggered by mitral valve prolapse ${ }^{4}$ opened a new era in the investigation of the mitral valve.

The Barlow valve still poses technical challenges to surgeons due to its multifaceted pathoanatomical presentation with bileaflet involvement with abnormally thickened leaflet tissue, gross involvement of the subvalvular apparatus, and annular dilatation. ${ }^{5}$ The main aspects of the disease are too much leaflet tissue and abnormal annular function. Pooling this all together, one understands that correction of the Barlow valve is more complex than for other disease forms. This complexity influences outcomes, although experienced centers report freedom from reoperation for regurgitation of $85 \%$ to $90 \%$ at 10 years. $^{6-8}$

In this issue of the Journal, Barlow and colleagues ${ }^{9}$ briefly review this complex anatomical-functional

From the a Department of Cardiac Surgery, University Hospital Zürich, Zürich, Switzerland; 'bepartment of Cardiothoracic Surgery, The University of the Free State, Bloemfontein, South Africa; ${ }^{\text {c} D e p a r t m e n t ~ o f ~ C a r d i a c ~ S u r g e r y, ~ H o s p i t a l ~ U n i-~}$ versitario "Alvaro Cunqueiro," Vigo, Spain; and ${ }^{\mathrm{d}}$ Department of Cardiovascular Surgery, Hospital Clinic de Barcelona, University of Barcelona, Barcelona, Spain. Disclosures: The authors reported no conflicts of interest.

The Journal policy requires editors and reviewers to disclose conflicts of interest and to decline handling or reviewing manuscripts for which they may have a conflict of interest. The editors and reviewers of this article have no conflicts of interest.

Received for publication Sept 26, 2021; revisions received Sept 26, 2021; accepted for publication Oct 6, 2021; available ahead of print Oct 9, 2021.

Address for reprints: Carlos A. Mestres, MD, PhD, FETCS, Department of Cardiac Surgery, University Hospital Zürich, Rämistrasse 100, CH-8091 Zürich, Switzerland (E-mail: Carlos.Mestres@usz.ch).

JTCVS Techniques 2021;10:66-7

2666-2507

Copyright (C 2021 The Author(s). Published by Elsevier Inc. on behalf of The American Association for Thoracic Surgery. This is an open access article under the CC BY license (http://creativecommons.org/licenses/by/4.0/).

https://doi.org/10.1016/j.xjtc.2021.10.006

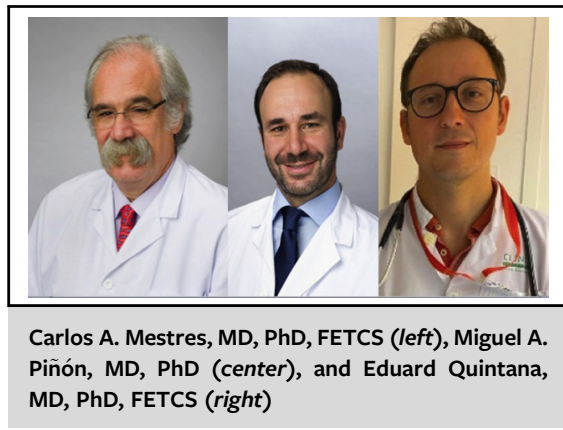

CENTRAL MESSAGE

This historical summary of the main aspects of the Barlow valve helps readers to understand the complexity of this pathoanatomical and functional disease and the best approach for successful surgery.

interaction, ${ }^{9}$ a very useful historical summary. As we previously pointed out, history helps in understanding. ${ }^{10}$ This is the case here. Why? John Barlow started from the clinical observation and examination of patients with a midsystolic click and late systolic murmur and palpitations, based on his interest in cardiac sounds, ${ }^{11}$ before echocardiography. From there, the Barlow valve has been established as individual entity. ${ }^{5}$ Modern echocardiography has helped to better understand the sequence of events until mitral regurgitation becomes significant. ${ }^{12,13}$ Surgical experiences with follow-up outcomes allowed us to confirm these valves are amenable for repair. ${ }^{3}$

Additional investigations showed that pathoanatomic changes in the form of annular abnormalities like disjunction should not be separated from the disease complex. ${ }^{14}$ The annular "instability" also may play a role in the development of ventricular arrhythmias. ${ }^{15}$ There is ongoing research regarding genetic etiology in mitral valve prolapse, something unknown with few genes identified. Van Wijngaarden and colleagues ${ }^{16}$ suggest some association between cardiomyopathy genes and prolapse, needing further investigation.

Surgery of the Barlow valve aims at restoring competence, releasing leaflet tension, and achieving leaflet coaptation. Another issue is like in other repairs what may eventually happen with the left ventricle ${ }^{17}$ or if surgery should be performed before significant regurgitation 
develops. ${ }^{9}$ Considering the Barlow valve, symmetry is also an issue, as there is bileaflet billowing and prolapse. The disease cannot easily be replicated as a regular P2 prolapse in a model for bench simulation. Imbrie-Moore and colleagues ${ }^{18}$ developed a cross-species model of the disease for biomechanical analyses of repair techniques in an ex vivo model. With all the limitations in mind, it may help improving knowledge and test the ability to repair.

This elegant and comprehensive historical review of Barlow and colleagues on the Barlow valve ${ }^{8}$ is another call for attention to the importance of reviewing history to understand the present and imagine the future.

\section{References}

1. Otto CM, Nishimura RA, Bonow RO, Carabello BA, Erwin JP III, Gentile F, et al. 2020 ACC/AHA guideline for the management of patients with valvular heart disease: a report of the American College of Cardiology/American Heart Association Joint Committee on clinical practice guidelines. Circulation. 2021;143: e72-227.

2. Enriquez-Sarano M, Suri RM, Clavel MA, Mantovani F, Michelena HI, Pislaru S, et al. Is there an outcome penalty linked to guideline-based indications for valvular surgery? Early and long-term analysis of patients with organic mitral regurgitation. J Thorac Cardiovasc Surg. 2015;150:50-8.

3. Dreyfus GD, Dulguerov F, Marcacci C, Haley SR, Gkouma A, Dommerc C, et al. "Respect when you can, resect when you should": a realistic approach to posterior leaflet mitral valve repair. J Thorac Cardiovasc Surg. 2018;156:1856-66.

4. Barlow JB, Pocock WA. The significance of late systolic murmurs and mid late systolic clicks. Md State Med J. 1963;12:76-7.

5. Anyanwu AC, Adams DH. Etiologic classification of degenerative mitral valve disease: Barlow's disease and fibroelastic deficiency. Semin Thorac Cardiovasc Surg. 2007;19:90-6.

6. Anyanwu AC, Adams DH. Bileaflet repair for Barlow syndrome. Semin Thorac Cardiovasc Surg. 2010;22:179-83.
7. Borger MA, Kaeding AF, Seeburger J, Melnitchouk S, Hoebartner M, Winkfein M, et al. Minimally invasive mitral valve repair in Barlow's disease early and long-term results. J Thorac Cardiovasc Surg. 2014;148:1379-85.

8. da Rocha E Silva JG, Spampinato R, Misfeld M, Seeburger J, Pfanmüller B, Eifert S, et al. Barlow's mitral valve disease: a comparison of neochordal (loop) and edge-to-edge (Alfieri) minimally invasive repair techniques. Ann Thorac Surg. 2015;100:2127-33.

9. Barlow CW, Ali-Ghosh H, Sajiram S. Functional anatomy and surgical principles of mitral repair for the Barlow valve: past legacy guides the future. J Thorac Cardiovasc Surg Tech. 2021;10:58-63.

10. Mestres CA. Do not forget to read history: you will understand and improve. J Thorac Cardiovasc Surg Tech. September 6, 2021 [Epub ahead of print].

11. Barlow JB. Some observations on the atrial sound. S Afr Med J. 1960;34:887-92.

12. van Wijngaarden SE, Kamperidis V, Regeer MV, Palmen M, Schalij MJ, Klautz RJ, et al. Three-dimensional assessment of mitral valve annulus dynamics and impact on quantification of mitral regurgitation. Eur Heart J Cardiovasc Imaging. 2018:19:176-84

13. Hiemstra YL, Tomsic A, Gripari P, van Wijngaarden AL, van der Pas SL, Palmen M, et al. Evolution from mitral annular dysfunction to severe mitral regurgitation in Barlow's disease. Interact Cardiovasc Thorac Surg. 2021;32: 506-14.

14. Faletra FF, Leo LA, Paiocchi VL, Schlossbauer SA, Pavon AG, Ho SY, et al. Morphology of mitral annular disjunction in mitral valve prolapse. $J$ Am Soc Echocardiogr. September 8, 2021 [Epub ahead of print].

15. van Wijngaarden AL, de Riva M, Hiemstra YL, van der Bijl P, Fortuni F, Bax JJ, et al. Parameters associated with ventricular arrhythmias in mitral valve prolapse with significant regurgitation. Heart. 2021;107:411-8.

16. van Wijngaarden AL, Hiemstra YL, Koopmann TT, Ruivenkamp CAL, Aten E, Schalij MJ, et al. Identification of known and unknown genes associated with mitral valve prolapse using an exome slice methodology. J Med Genet. 2020; 57:843-50.

17. Quintana E, Suri RM, Thalji NM, Daly RC, Dearani JA, Burkhart HM, et al, Left ventricular dysfunction after mitral valve repair-the fallacy of "normal" preoperative myocardial function. J Thorac Cardiovasc Surg. 2014;148: 2752-60.

18. Imbrie-Moore AM, Paulsen MJ, Zhu Y, Wang H, Lucian HJ, Farry JM, et al. A novel cross-species model of Barlow's disease to biomechanically analyze repai techniques in an ex vivo left heart simulator. J Thorac Cardiovasc Surg. 2021, 161:1776-83. 